\title{
Study of a Wind Front over the Northern South China Sea Generated by the Freshening of the North-East Monsoon
}

\author{
Werner Alpers ${ }^{1}$. Wai Kin Wong ${ }^{2}$. \\ Knut-Frode Dagestad ${ }^{3}$. Pak Wai Chan ${ }^{2}$
}

Received: 21 November 2014 / Accepted: 1 June 2015 / Published online: 25 June 2015

(C) The Author(s) 2015. This article is published with open access at Springerlink.com

\begin{abstract}
Wind fronts associated with cold-air outbreaks from the Chinese continent in the winter are often observed over the northern South China Sea and are well studied. However, wind fronts caused by another type of synoptic setting, the sudden increase or freshening of the north-east monsoon, which is caused by the merging of two anticyclonic regions over the Chinese continent, are also frequently encountered over the northern South China Sea. For the first time, such an event is investigated using multi-sensor satellite data, weather radar images, and a high-resolution atmospheric numerical model. It is shown that the wind front generated by the freshening of the north-east monsoon is quite similar to wind fronts generated by cold-air outbreaks. Furthermore, we investigate fine-scale features of the wind front that are visible on synthetic aperture radar (SAR) images through variations of the small-scale sea-surface roughness. The SAR image was acquired by the Advanced SAR of the European Envisat satellite over the South China Sea off the coast of Hong Kong and has a resolution of $150 \mathrm{~m}$. It shows notches (dents) in the frontal line and also radar signatures of embedded rain cells. This (rare) SAR image, together with a quasi-simultaneously acquired weather radar image, provide excellent data with which to test the performance of the pre-operational version of the Atmospheric Integrated Rapid-cycle (AIR) forecast model system of the Hong Kong Observatory with respect to modelling rain cells at frontal boundaries. The calculations using a horizontal resolution with 3-km resolution show that the model reproduces quite well
\end{abstract}

\footnotetext{
$凶 \quad$ Werner Alpers

alpers@ifm.uni-hamburg.de

Wai Kin Wong

wkwong@hko.gov.hk

Knut-Frode Dagestad

knutfd@met.no

Pak Wai Chan

pwchan@hko.gov.hk

1 Institute of Oceanography, University of Hamburg, Bundesstrasse 53, 20146 Hamburg, Germany

2 Hong Kong Observatory, 134A Nathan Road, Tsim Sha Tsui, Hong Kong

3 Norwegian Meteorological Institute, Allégaten 70, 5007 Bergen, Norway
} 
the position of the notches where rain cells are generated. The model shows further that at the position of the notches the vorticity of the airflow is increased leading to the uplift of warmer, moister air from the sea-surface to higher levels. With respect to the $10-\mathrm{km}$ resolution model, the comparison of model data with the near-surface wind field derived from the SAR image shows that the AIR model overestimates the wind speed in the lee of the coastal mountains east of Hong Kong, probably due to the incorrect inclusion of the coastal topography.

Keywords Atmospheric numerical model $\cdot$ Multi-sensor satellite observations $\cdot$ North-east monsoon · Rain cells · South China Sea · Synthetic aperture radar · Wind field · Wind front

\section{Introduction}

During the winter monsoon season in south-east Asia, often strong wind events occur along the Chinese coast of the South China Sea (SCS). When these flows encounter the ambient flow over the SCS, they form wind fronts, which are detectable from space, using e.g. synthetic aperture radars, by the variation of the small-scale sea-surface roughness (see Sect. 3). During such strong wind events, cold air from Siberia, Mongolia or northern China advances southward over the Chinese continent, reaching the Chinese coast and advancing further over the SCS. These events occur in the form of cold-air outbreaks and are associated with a sudden increase or freshening of the wind from a northerly direction and a sudden decrease in air temperature. In Hong Kong, they are referred to as cold or northerly winter monsoon surges and occur most frequently between November and February, typically one to two times per month, and may last from few days to one week or more (Wu and Chan 1995, 1997; Zhang et al. 1997; Chang et al. 2005). Northerly surges have been studied extensively using conventional meteorological data (see, e.g., Ramage 1971; Boyle and Chen 1978; Lim and Chang 1981; Chang et al. 1983, 2005; Chu and Park 1984; Johnson and Zimmermann 1986; Wu and Chan 1995; Zhang et al. 1997; Chen et al. 2004), and recently also by using satellite data, in particular synthetic aperture radar (SAR) data (Alpers et al. 2012).

Here we report on a high wind-speed event that is not caused by a cold-air outbreak, but by the freshening of the north-east monsoon winds due to the merging of two anticyclonic regions over the Chinese continent. Such an event was observed in December 2009, which gave rise to a similar sharp wind front over the SCS as observed in northerly surges. It is associated locally with a decrease in air temperature, but usually this temperature decrease is much smaller than in northerly surges. The frontal line results in this case from the interaction of two air masses: one of continental origin flowing through the Strait of Taiwan into the SCS and the other, being warmer and more humid, residing over the warm SCS. This kind of wind front is of interest because it is not associated with a large-scale surge as encountered during outbreaks of cold air from the inland area (Mongolia-Russia region), but is associated with a relatively weak replenishment of cold air from the north. Such weak surges occur quite often in the region-several times per year in winter/spring over eastern China. To our knowledge, such wind fronts have not been studied before using jointly multi-sensor observations and numerical simulations. The data show that this wind front is as sharp as those cold fronts associated with cold-air outbreaks, and also containing embedded rain cells. We compare the observations with simulations carried out with the pre-operational version of the Atmospheric Integrated Rapid-cycle (AIR) forecast model of the Hong Kong Observatory (Wong 2010) with horizontal resolutions of 10 and $3 \mathrm{~km}$. 
The paper is organized as follows: in Sect. 2, we describe the meteorological setting that gave rise to the merging of two anticyclones over the Chinese continent and the subsequent freshening of the north-east monsoon winds generating the atmospheric front over the SCS. In Sect. 3, we present the remote sensing data used in this investigation: (1) scatterometer data from the Advanced Scatterometer (ASCAT) onboard the European MetOp satellite (http://www.esa.int/export/esaME/ascat.html), (2) synthetic aperture radar (SAR) data from the Advanced SAR (ASAR) onboard the European Envisat satellite (https://earth.esa. int/web/guest/missions/esa-operational-eo-missions/envisat/instruments/asar), (3) weather radar data from the Hong Kong weather radar, which is an S-band radar with a beamwidth of 0.9 degrees located on the top of a hill at a height of $970 \mathrm{~m}$ above mean sea level, which performs volume scans at 10 elevation angles (http://www.hko.gov.hk/wxinfo/radars/radar. $\mathrm{htm}$ ), and (4) optical data (cloud images) from the Japanese geostationary satellite MTSAT1R (http://www.jma.go.jp/jma/jma-eng/satellite). In Sect. 4, we compare the remote sensing data with simulations carried out with the AIR forecast model and show that this mesoscale numerical weather prediction model system reproduces quite well the main observed features of this event. Finally, in Sect. 5, we summarize our results.

\section{The Meteorological Setting}

The weather situation encountered during this event is shown in four weather analysis charts depicted in Figs. 1 and 2, which are referenced to mean sea-level pressure and valid for 0000 UTC on 28, 29, 30, and 31 December 2009, respectively. The synoptic pattern of 28 December 2009 (Fig. 1a) shows that an anticyclone resided over south-eastern China centered at Nanchang (Jiangxi Province, China), maintaining a north-easterly monsoonal flow over southern China and the northern part of the South China Sea. On 29 December, the northeast monsoonal flow weakened as evidenced by the isobars in Fig. 1b. Between these two dates, the centre of the anicyclone moved southward resulting in a change in wind direction over southern China from east to north-east. On this day, another anticyclone emerged over northern China, which, on 30 December, merged with the anticyclone over the east coast of China, leading to a freshening of the north-east monsoon (Fig. 2a). At 0000 UTC on 30
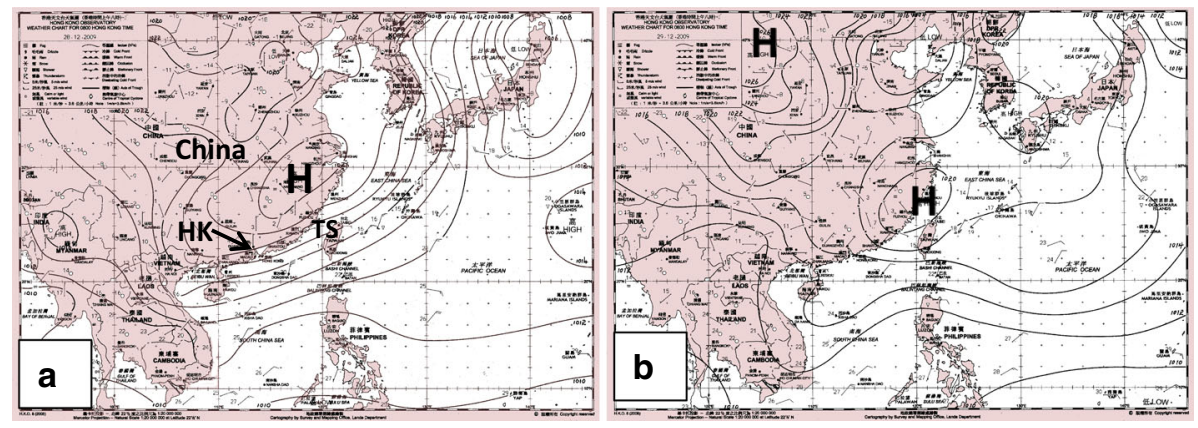

Fig. 1 a Weather synopsis (at mean sea level) of south-east Asia valid for 0000 UTC on 28 December 2009 showing a high pressure area $(\mathrm{H})$ residing over south-eastern China north-east of Hong Kong (HK) giving rise to north-easterly winds over southern China and the northern South China Sea. b Same as a, but valid for 0000 UTC on 29 December 2009 showing that the high pressure area over southern China has moved further south with a veering of the wind to easterly in the Hong Kong area. Furthermore, there is evidence of another high pressure area over northern China. TS denotes the Strait of Taiwan 

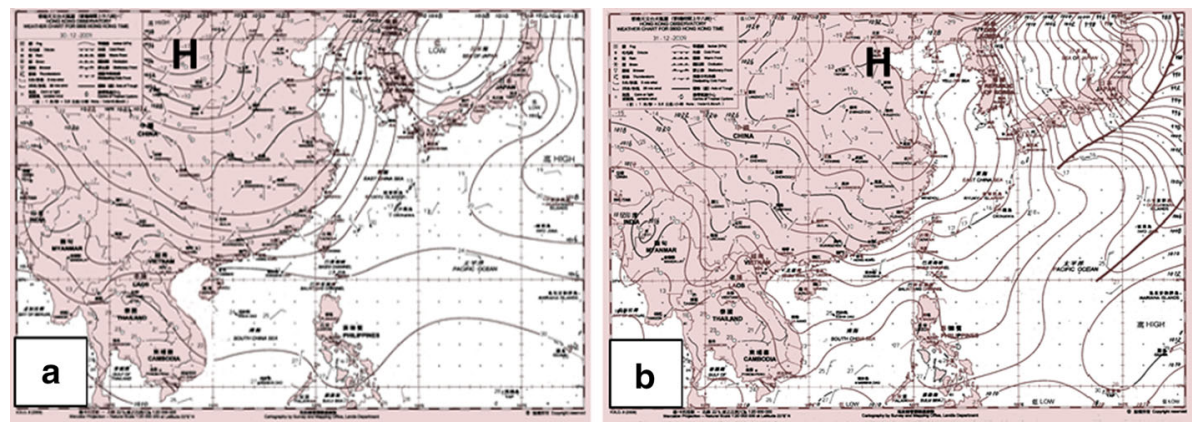

Fig. 2 a Same as Fig. 1a, but valid for 0000 UTC on 30 December 2009 showing that the high pressure area over eastern China has merged with the high pressure area over northern China leading to a freshening of the north-east monsoon. b Same as a, but valid for 0000 UTC on 31 December 2009, showing that the high pressure gradient is located south of Hong Kong

December, the high pressure gradient was still maximum over the Chinese continent, while on 31 December (Fig. 2b), the maximum was located over the northern South China Sea. Thus the maximum in the horizontal pressure gradient must have crossed the coast near Hong Kong between these two dates, and therefore the freshening of the wind must have taken place at Hong Kong between these two dates.

We infer from the analysis charts that the cold air, before reaching the sea area south of Hong Kong, has travelled along the east coast of China long distances over warm waters and thus has taken up heat and moisture from the ocean. The air temperature was $18^{\circ} \mathrm{C}$ at ground level when the air mass from the north-east reached Hong Kong (around 1400 UTC on 30 December). The sea-surface temperature near Hong Kong was at that time around $22{ }^{\circ} \mathrm{C}$ implying that the near-surface atmospheric layer was unstable (water temperature was $4{ }^{\circ} \mathrm{C}$ higher than the air temperature) triggering atmospheric convection. This implies that the near-surface atmospheric layer was unstable leading to an intensification of momentum transfer (wind stress) from the marine boundary layer towards the sea surface and thus to an increase in the near-surface wind speed. This accords with the TOGA COARE wind-stress computations, which take into account dynamical and thermodynamical processes and are based on data collected during the the Tropical Ocean Global Atmosphere (TOGA) Coupled Ocean-Atmosphere Response (COARE) Experiment (Fairall et al. 1996).

Another reason for the high wind speed behind the wind front is probably the ageostrophic effect associated with the spreading of the cooler air towards the northern part of the South China Sea. This phenomenon is quite common when the north-east monsoon from inland China freshens (or "replenishes", a term often used by meteorologists engaged in monsoon research). The radiosonde measurements for the King's Park station in Hong Kong show that at 0000 UTC on 30 December 2009 the air temperature remained the same between 500 and $1000 \mathrm{~m}$ above sea level, with the height of the boundary layer about $1000 \mathrm{~m}$.

\section{Remote Sensing Data}

\subsection{ASCAT Data}

Figure $3 \mathrm{a}$ and $\mathrm{b}$ show near-surface wind fields measured by ASCAT onboard the European MetOp satellite at 1358 UTC (2158 Hong Kong local time (LT)) on 29 December and at 0226 

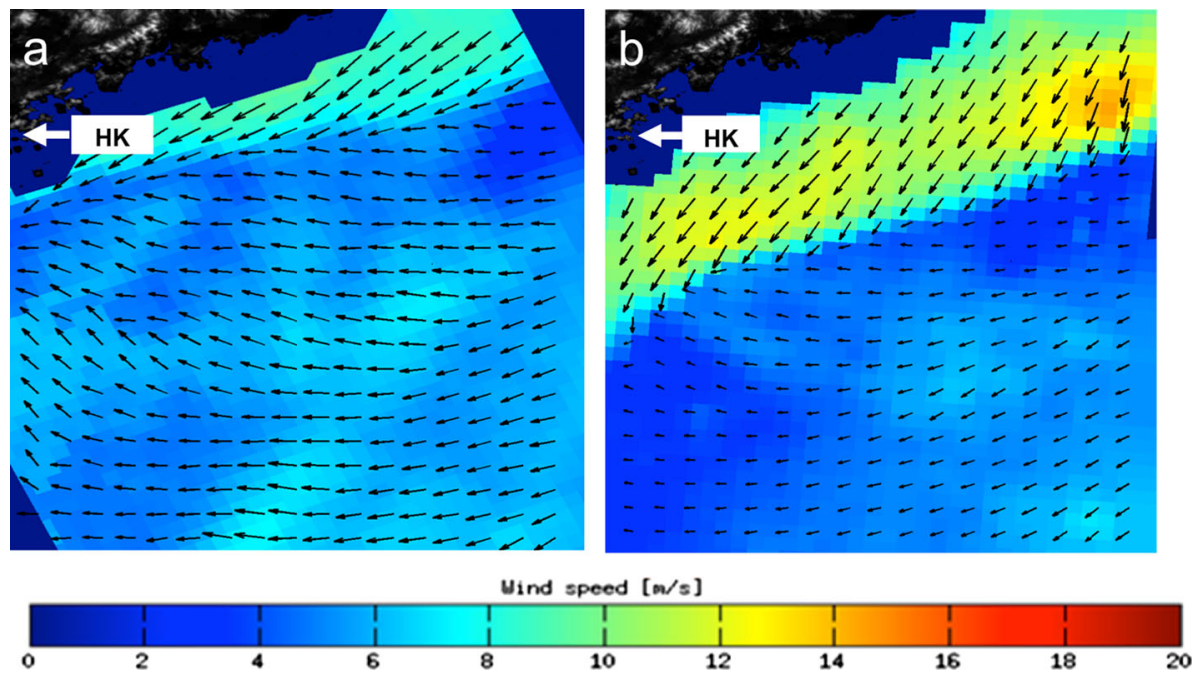

Fig. 3 a Near-surface wind field retrieved from data from the ASCAT scatterometer onboard the MetOp satellite at 1358 UTC (2158 LT) on 29 December 2009 and b at 0227 UTC (1029 LT) on 30 December 2009

UTC (1026 LT) on 30 December, respectively. This microwave instrument, which operates at C-band $(5.255 \mathrm{GHz})$, measures the near-surface wind speed and direction indirectly via the small-scale sea-surface roughness (see, e.g., Valenzuela 1978; Stoffelen and Anderson 1997; Yang et al. 2011). It obtains the near-surface wind field on both sides of the satellite track along two swathes that have widths of approximately $500 \mathrm{~km}$. ASCAT has six antennas, three looking to each side of the satellite track. The spatial resolution is $25 \mathrm{~km}$, and the data are digitized at a spacing of $12.5 \mathrm{~km}$. The wind fields retrieved from ASCAT data are referenced to a height of $10 \mathrm{~m}$ above the sea surface.

Figure 3a shows a distinct high wind-speed band with speeds between 8 and $11 \mathrm{~m} \mathrm{~s}^{-1}$ (greenish colours) adjacent to the coast. Note that, due to the coarse resolution of $25 \mathrm{~km}$, ASCAT cannot measure the wind field close to the coast, because at distances smaller than $25 \mathrm{~km}$ the resolution cell contains land targets that contaminate the backscattered radar signal. Figure $3 \mathrm{~b}$ shows that $12 \mathrm{~h} 28 \mathrm{~min}$ later (at 0226 UTC), the frontal line has moved further south. At this time, the wind speed in the coastal band has increased to a maximum of $14 \mathrm{~m} \mathrm{~s}^{-1}$ (reddish colour).

\subsection{ASAR Data}

Figure 4 shows an ASAR image of the sea area south of Hong Kong that was acquired only 14 min earlier (at 0213 UTC on 30 December) than the ASCAT data shown in Fig. 3b. As with ASCAT, ASAR is also an active microwave instrument, which operates also in the $\mathrm{C}$-band $(5.300 \mathrm{GHz})$, but has a much higher spatial resolution. This ASAR image was acquired during a descending satellite pass in the VV mode, i.e., the emitted radar beam was vertically polarized and the scattered radar beam was received also in vertical polarization. The swath width is $400 \mathrm{~km}$, and the resolution is $150 \mathrm{~m}$ on the ground. It is a map of the normalized radar cross-section (NRCS) that is related to the near-surface wind vector by an empirical function, the geophysical model function (Stoffelen and Anderson 1997). According to Bragg scattering theory (Valenzuela 1978), the NRCS increases with increasing 


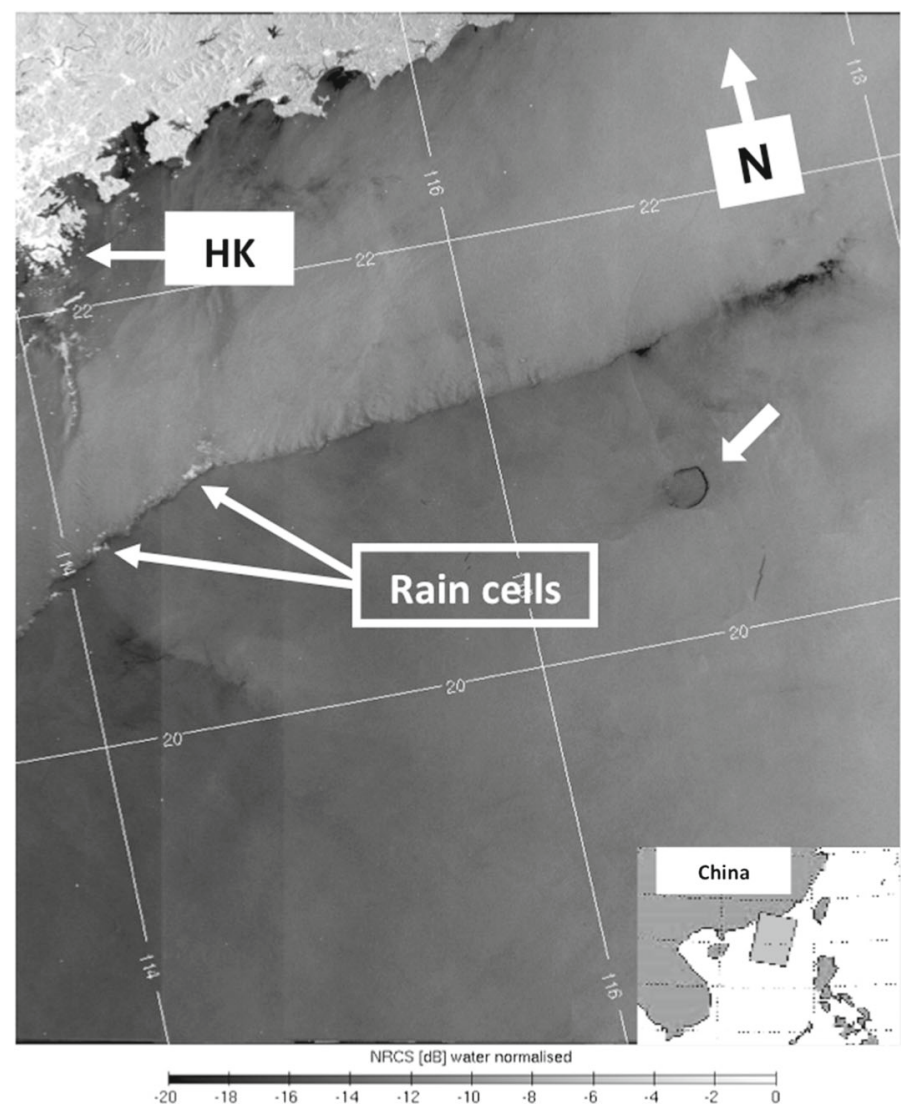

Fig. 4 SAR image acquired by Envisat ASAR in the Wide Swath mode (VV polarization) at 0213 UTC (1013 LT) on 30 December 2009 over the Chinese coast of the South China Sea near Hong Kong (HK). The black circle-like feature marked by a broad white arrow is the coral reef of Dongsha island. The imaged area is $510 \mathrm{~km} \times 660 \mathrm{~km}$. The inset shows the location of the SAR scene in the South China Sea. @ ESA

near-surface wind speed. Visible in the upper left corner are the Chinese coast with Hong Kong and in the central right section the coral reef of Dongsha island (the black circle-like feature marked by broad white arrow). Almost parallel to the coast line is visible a broad band of increased image brightness (or NRCS) caused by increased sea-surface roughness and thus by increased near-surface wind speed. Noteworthy is the sharp southern boundary of this roughness band, which marks the frontal line (wind front). Its offshore distance near Hong Kong is approximately $110 \mathrm{~km}$ and increases towards the east to more than $150 \mathrm{~km}$. Elongated dark patches are visible adjacent to the frontal boundary (on the southern side) in the eastern section of the image. We interpret these as radar signatures of surface films, probably consisting of mineral oil released from ships or oil platforms that dampen the short surface waves and thus reduce the radar backscattering or the NRCS (Valenzuela 1978). They appear darker on radar images than the surrounding areas. The bright spots embedded in the frontal line, as well as the bright line north of these bright spots, are radar signatures of rain cells as evidenced by a quasi-simultaneously acquired weather radar image (Fig. 7).

Figure 5 shows the near-surface wind field retrieved from this ASAR image. Note that, due to its finer resolution, ASAR measures the near-surface wind field much closer to the coast 


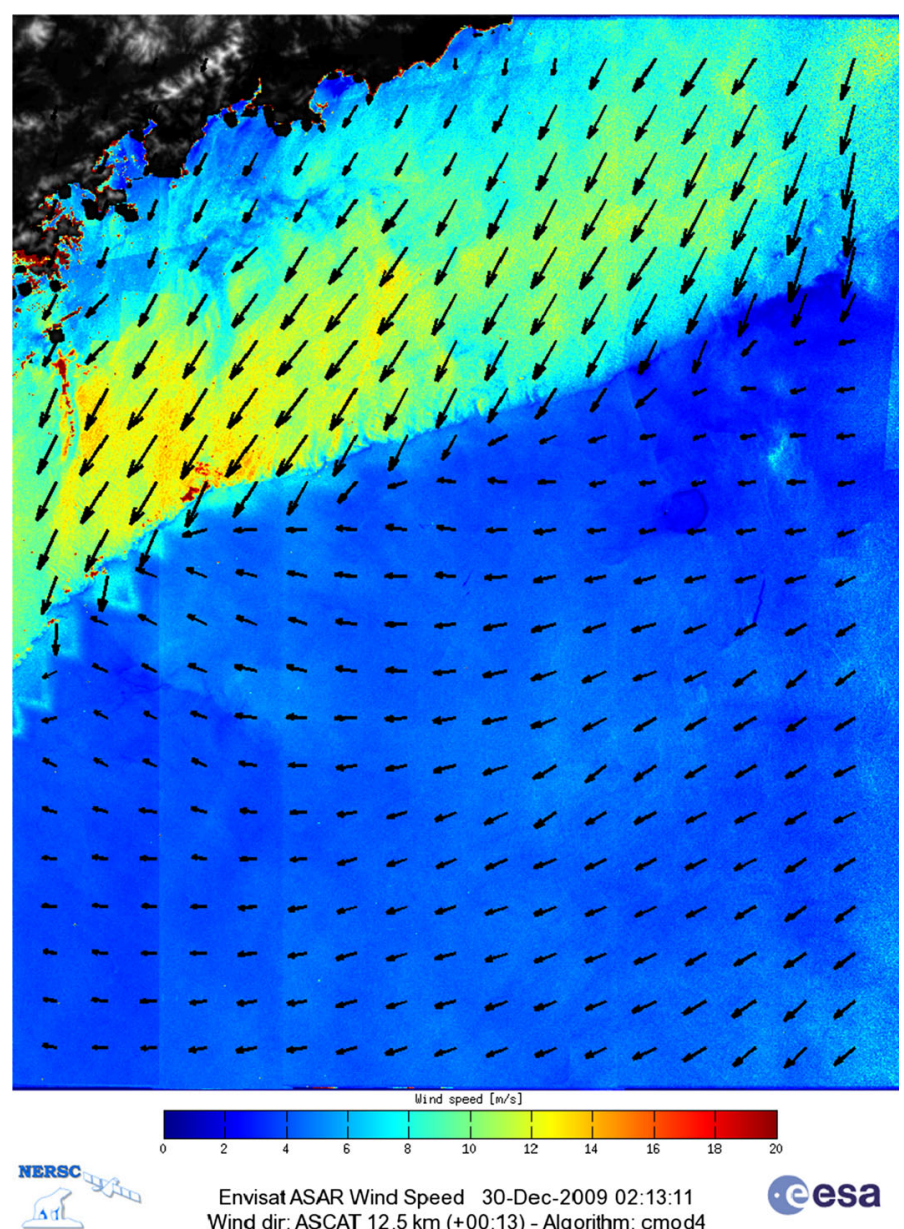

Fig. 5 Near-surface wind field retrieved from the ASAR image by using the wind direction measured by ASCAT 13 min after ASAR data acquisition (see Fig. 4) and, near the coast, calculated by the NCEP model

than with ASCAT. Here the wind field has been processed to a resolution of $1 \mathrm{~km} \times 1 \mathrm{~km}$ for a more accurate estimate of the wind speed. The retrieval of near-surface wind fields from SAR data is not as straightforward as from scatterometer data. While scatterometers measure the backscattered radar power from a resolution cell on the sea-surface from (at least) three different azimuth directions, SAR measures it only from one direction, perpendicular to the satellite flight direction. Thus, in order to retrieve (two-dimensional) wind fields from SAR images, one has to obtain the wind direction from sources other than from NRCS data (Monaldo et al. 2001, 2003; Horstmann and Koch 2005; Sikora et al. 2006; Alpers et al. $2009,2010,2012,2015)$. This directional information can be obtained from, (1) atmospheric numerical models, (2) linear features (often, but not always) visible on the SAR images, which are assumed to be aligned in wind direction, (3) Doppler information inherent in the backscattered SAR signals (Mouche et al. 2012; Alpers et al. 2015) or (4) sensors measuring wind direction in situ, e.g., from sea-based platforms. In our case, we have taken the wind direction from ASCAT data acquired 14 min after the ASAR data acquisition, see Fig. $3 \mathrm{~b}$. 


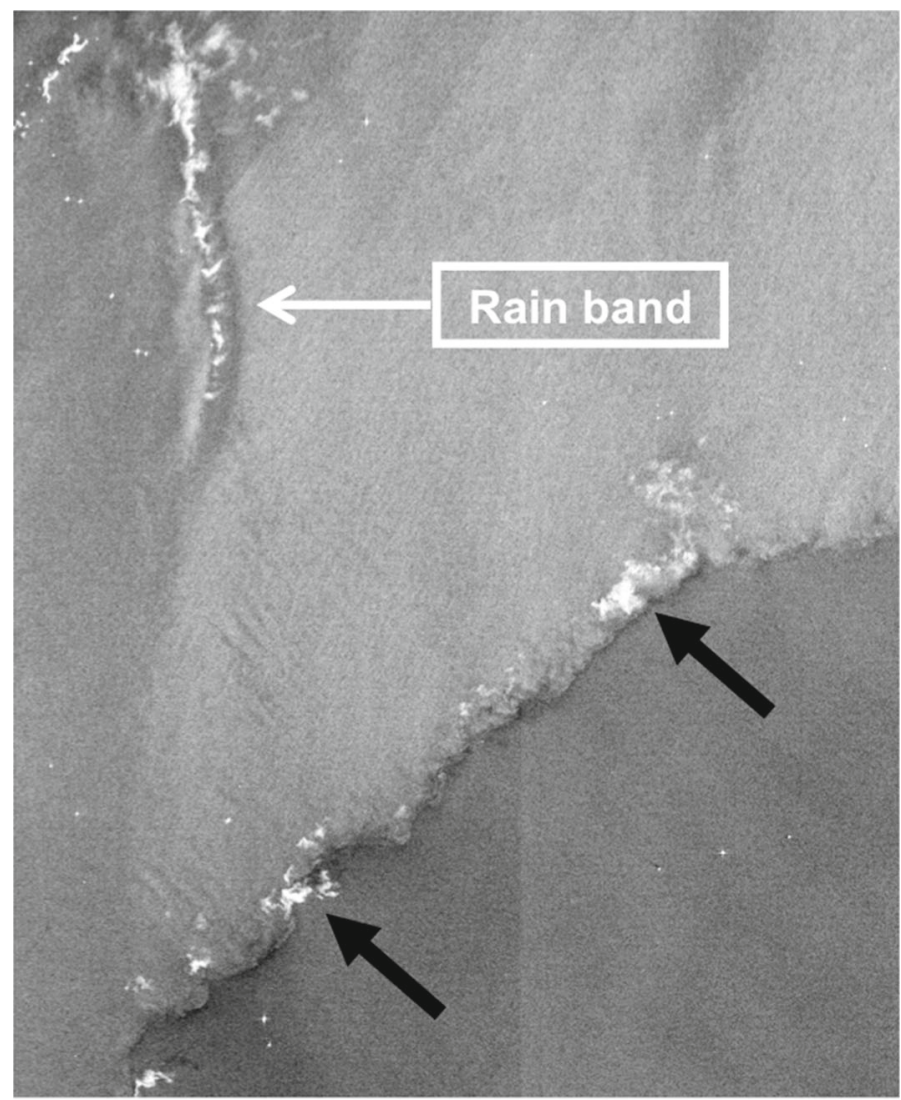

NRCS $[d B]$ water normalised

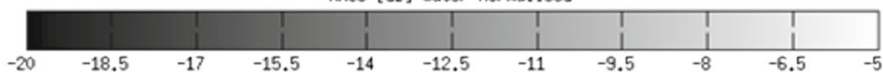

Fig. 6 Zoom on the central western section of the SAR image depicted in Fig. 4 showing details of the frontal boundary. The bright patches are radar signatures of rain cells. The radar signatures of rain cells marked by dark arrows are located at positions where the weather radar image (Fig. 7) shows strong rain cells. To the north, also the radar signature of another rainband is visible (see Fig. 7)

Close to the coast, where ASCAT has no coverage due to land contamination in the signal, we have supplemented it with wind directions provided by the atmospheric model of the National Centers for Environmental Prediction of the United States. It provides global wind fields every $3 \mathrm{~h}$ at a grid spacing of $0.5^{\circ}$ in latitude and longitude. Here we have taken the data valid for 0300 UTC, i.e., $47 \mathrm{~min}$ after the ASAR data acquisition. For the inversion of the NRCS values into wind speed, we have used the " $C$-Band Wind Scatterometer Model Function version 4" (CMOD4) (Stoffelen and Anderson 1997), which was originally developed to retrieve near-surface wind fields from data of the wind scatterometer onboard the European ERS-1 and ERS-2 satellites. Figure 5 shows that the strongest winds were encountered at off-shore distances between 80 and $100 \mathrm{~km}$ and the weakest winds near the coast. We attribute the low wind speed near the coast to shadowing caused by elevated coastal topography east of Hong Kong. The sea area where radar signatures of rain cells (bright patches) are visible 


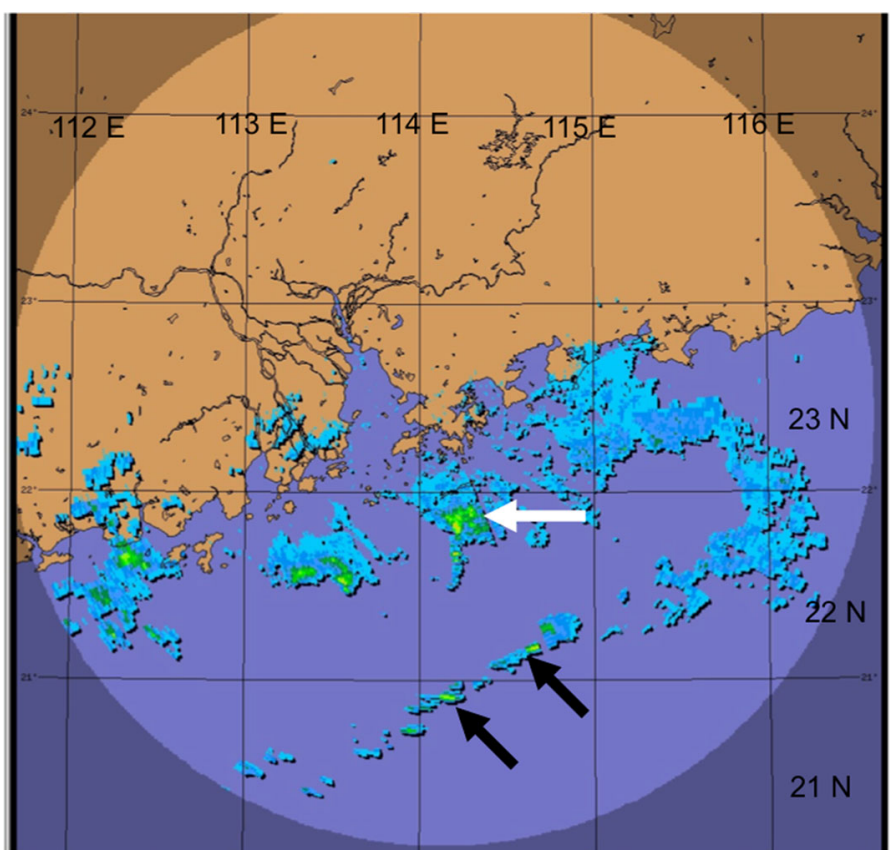

Fig. 7 Radar reflectivity image acquired by the Hong Kong weather radar at 0212 UTC (1012 LT) on 30 December 2009 showing the distribution of rainfall around Hong Kong. After converting radar reflectivity into rainfall rate, green/yellow colours denote rainfall rates of $15-30 \mathrm{~mm} \mathrm{~h}^{-1}$ and blue colours denote rainfall rates of $0.5-2 \mathrm{~mm} \mathrm{~h}^{-1}$. Note that the position of the rainband with two strong rain cells marked by black arrows coincides with the position of the frontal line visible on the ASAR image depicted in Fig. 4. Also the rainband further north marked by a white arrow has its correspondence in the SAR image (Figs. 4,6 )

on the SAR image (Fig. 4) is shown in greater detail in Fig. 6. Evidence of this interpretation is provided by the quasi-simultaneously acquired weather radar image depicted in Fig.7.

\subsection{Weather Radar and MTSAT-1R Cloud Data}

Figure 7 shows the radar reflectivity image (converted into rainfall rate) acquired by the Hong Kong weather radar at 0212 UTC (1012 LT) on 30 December, 1 min before the ASAR data acquisitions, note the two strong rain cells in the rainband marked by black arrows. Their positions closely correspond to the positions of the two distinct bright patches visible on the ASAR image (Fig. 6), which are also marked by black arrows. Vertical profiles of the radar reflectivity of the weather radar (not reproduced here) show that there was no melting layer that caused strong reflections of the radar beam at raindrops. Thus we conclude that the bright patches (areas of large NRCS) visible on the ASAR image result very likely from increased sea-surface roughness caused by sea-surface waves that are generated by raindrops impinging onto the sea surface and spread radially in the form of ring waves from the impact craters (Melsheimer et al. 1998). We have compared this weather radar image with a cloud image (1-km resolution) that was acquired in the visible band by the Japanese geostationary satellite MTSAT-1R over the South China Sea and the Chinese continent at 0157 UTC on 30 December, i.e., 16 min before the SAR data acquisition (not reproduced here). It shows clouds along the Chinese coast that have a sharp southern boundary, in particular, a narrow 

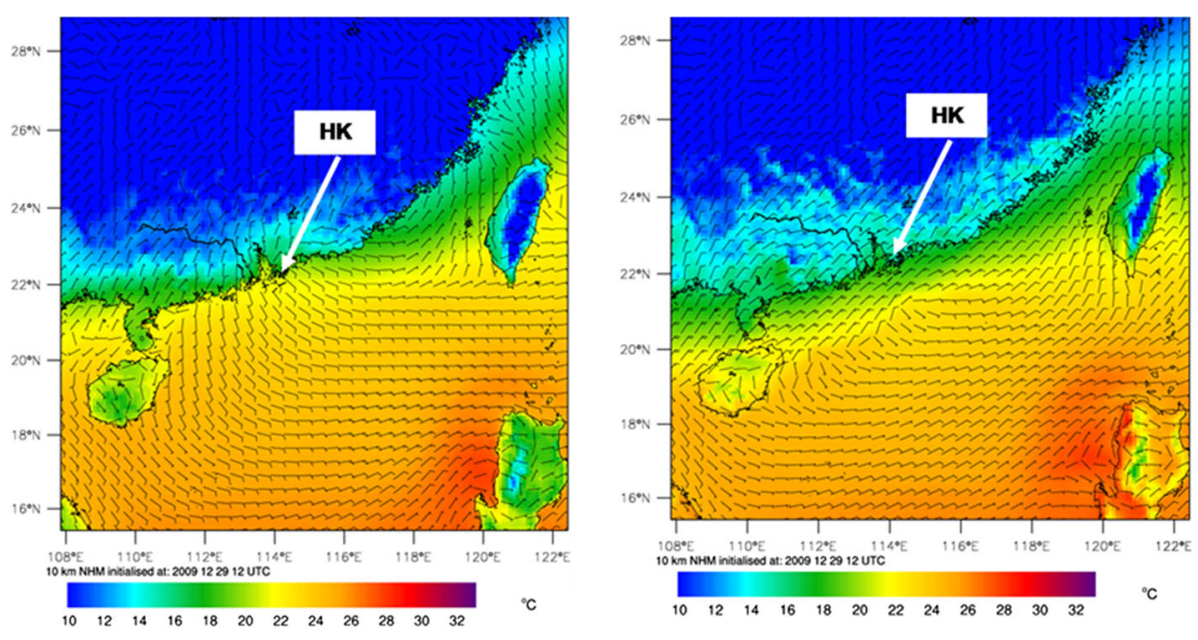

Fig. 8 Near-surface wind field (10-m level) and air temperature field ( $2 \mathrm{~m} \mathrm{level)} \mathrm{calculated} \mathrm{with} \mathrm{the} \mathrm{AIR}$ model with 10-km resolution for 1400 UTC on 29 December 2009 (left) and 0200 UTC on 30 December 2009 (right). The air temperature is shown by the colour coding and the wind vector by conventional wind barbs

line of enhanced cloud density is visible south of Hong Kong. This is at the location of the frontal system where strong convection developed and where rain cells are located.

\section{Comparison of Remote Sensing Data with Model Results}

Simulations carried out with the pre-operational version of the AIR forecast model system with $10-\mathrm{km}$ resolution for 0200 UTC (1000 LT) on 30 December are shown in Fig. 8; the simulation was initiated at 1200 UTC on 29 December. The initial condition was interpolated from the Global Spectral Model (GSM) 4DVAR analysis of the Japan Meteorological Agency (JMA) with horizontal resolution of 0.5 degrees in latitude and longitude. The physical parametrizations used in the model are described in detail in Wong (2010) where, in particular, the formulation of the surface flux and the bulk coefficients follows Beljaars and Holtslag (1991), and the convective parametrization is based on the Kain-Fritsch scheme (Saito et al. 2006). The lateral boundary conditions, available at 3-h intervals, are obtained from the same GSM forecast run at 1200 UTC on 29 December.

The near-surface wind field (arrows) together with the air temperature field (colour coding) are depicted in Fig. 8. This shows cold air flowing through the Strait of Taiwan in a southwestward direction, where to the west it encounters west of this strait a synoptic-scale flow of cold air from an easterly direction. A frontal line of flow convergence is generated where moist air is lifted upward with the potential for generating rain cells. The weather radar image depicted in Fig. 7 shows that at this time the area of rainfall terminates just east of Hong Kong and confirmed by the SAR image depicted in Fig. 4 that shows also no radar signature of rain cells east of this area. Simulations carried out with the inner domain of the pre-operational version of the AIR model with 3-km resolution for 0200 UTC (1000 LT) on 30 December are depicted in Figs. 9, 10, 11, and 12. The model run was initiated at 1800 UTC on 29 December with its initial condition taken from the outer 10-km AIR model forecast (i.e., $\mathrm{T}+6 \mathrm{~h}$ model forecast) and boundary conditions updated at 1-h intervals. The same physical 


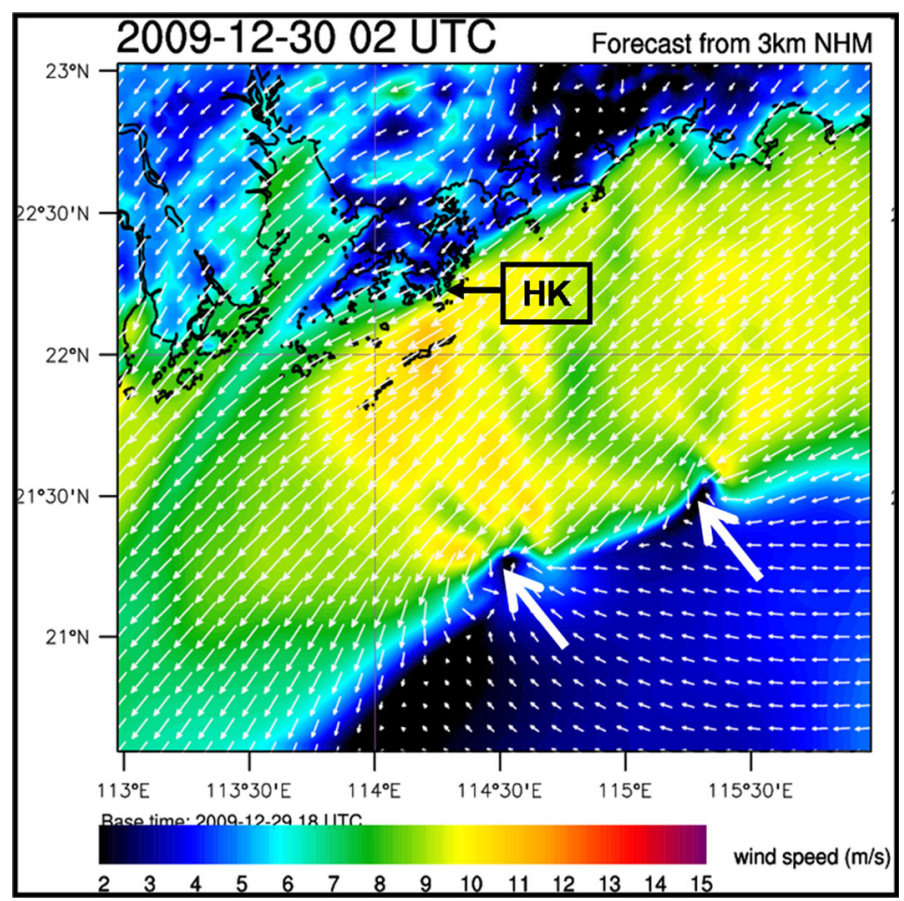

Fig. 9 Near-surface wind vectors and wind speed (colour coding) calculated with the AIR model with 3-km resolution for 0200 UTC (1000 LT) on 30 December 2009. Note the two notches in the frontal line marked by white arrows

parametrization schemes were used in the inner 3-km model run as in the $10-\mathrm{km}$ resolution model run.

The comparison of the simulated near-surface wind field valid for 0200 UTC (Fig. 9) with the SAR-derived wind field valid for 0213 UTC (Fig. 5) shows that the SAR-derived wind speed is lower in the coastal area east of Hong Kong (around $4 \mathrm{~m} \mathrm{~s}^{-1}$ ) than the simulated wind speed (between 8 and $10 \mathrm{~m} \mathrm{~s}^{-1}$ ). We attribute this difference to the fact that shadowing by the coastal mountains is not taken properly into account in the AIR model. We have also compared the position of the frontal line calculated by the AIR model (Fig. 9) with the position of the frontal line visible on the SAR image (Fig. 4) and with the position of cloud boundary visible on the MTSAT-1R image and found good agreement.

A peculiar feature visible in the simulated near-surface wind field (Fig. 9) is the presence of two notches (dents) in the frontal boundary where the near-surface wind vector rotates in an anticlockwise (cyclonic) direction. Their position coincides with the position of the areas of increased rainfall as seen in Fig. 10. The notches are located approximately at positions where the weather radar shows strong rain cells (Fig. 7) and where the SAR shows rain cells and notches (dents) in the frontal boundary (Fig. 6).

In order to obtain an insight into the mechanism that leads to the generation of notches/rain cells at the frontal boundary, we have calculated the relative vorticity field and the streamlines at $850-\mathrm{hPa}$ (about $1.5 \mathrm{~km}$ ) with the AIR model with 3-km resolution valid for 0200 UTC (1000 LT) on 30 December (Fig. 11). Figure 11 shows enhanced positive vorticity at the positions of the notches/rain cells and where the airflow turns leftward producing cyclonic motion. Thus warmer, moister air is uplifted in this area leading to the generation of rain cells at higher 


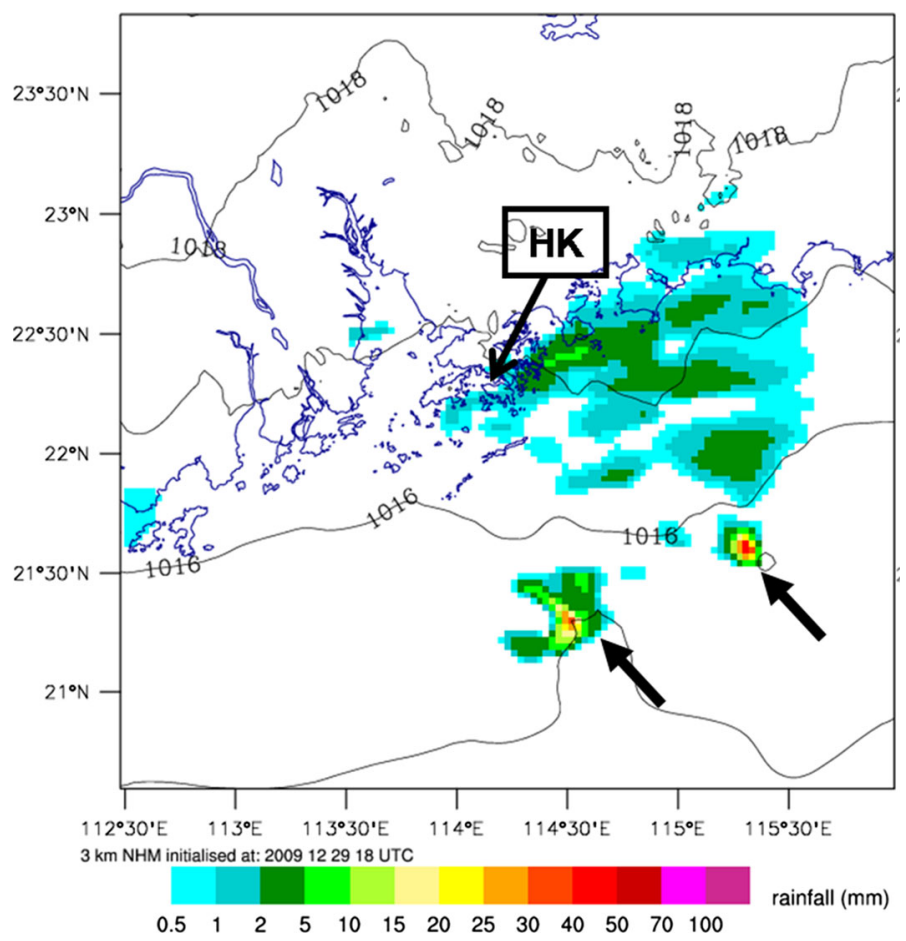

Fig. 10 Mean sea-level pressure (contour lines) and 1-h accumulated rainfall (colour coding) calculated with the AIR model with 3-km resolution for 0200 UTC (1000 LT) on 30 December 2009. Note the two distinct rain cells marked by arrows which are located at the positions where the frontal boundary has notches (Fig. 9)

levels. Note that the direction of the airflow at $850-\mathrm{hPa}$ is quite different (north-eastwards) from the wind direction near the sea surface (Fig. 9) producing vertical wind shear and thus contributing to strong updrafts. It is well known (see, e.g., Holton 1992, p. 274; Doswell $2001,2014)$ that vertical wind shear is instrumental in the mechanism generating supercells in severe storms. When an updraft develops in an environment with vertical wind shear, the updraft produces a perturbation pressure gradient force that increases the effect of positive buoyancy (Rotunno and Klemp 1982). Thus the increase of the updraft acceleration can result in a contribution to the updraft that is as large as that from buoyancy alone. Supercells generally have the strongest updrafts of any deep convective storms. By analogous reasoning, we expect that the same mechanism applies also in our case leading to strong updraft at the positions of the rain cells.

Figure 12 shows vertical cross-sections along the dashed line inserted in Fig. 11. Figure 12a shows the vertical cross-section of equivalent potential temperature $\left(\theta_{\mathrm{e}}\right)$ in kelvin (colour coding) and of specific humidity of rain water $\left(Q_{\mathrm{r}}\right)$ in units of $\mathrm{kg} \mathrm{kg}^{-1}$ (black contour lines with intervals of $5 \times 10^{-4} \mathrm{~kg} \mathrm{~kg}^{-1}$ ), and Fig. $12 \mathrm{~b}$ shows the vertical cross-sections of vertical velocity $(w)$ in $\mathrm{m} \mathrm{s}^{-1}$ (colour coding) and of pressure perturbation exceeding $100 \mathrm{~Pa}$ (blue contour lines with intervals of $10 \mathrm{~Pa}$ ). Figure 12a shows that, at the frontal boundary, colder, near-surface air from the north meets warmer, moist air from the south with the cold air undercutting the warm, moist air, leading to uplift of warm, moist air. Figure $12 \mathrm{~b}$ shows a narrow band of increased $Q_{\mathrm{r}}$ at the frontal boundary layer reaching a height of about $3 \mathrm{~km}$. At 


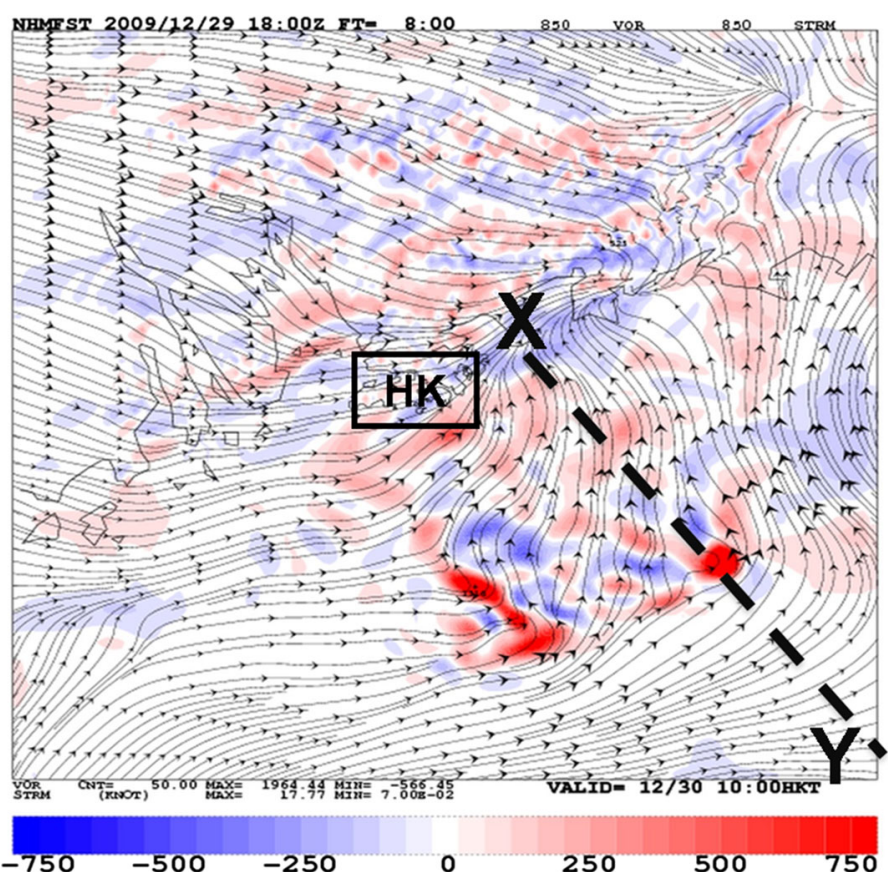

Fig. 11 Relative vorticity (colour coding in unit of $10^{-6} \mathrm{~s}^{-1}$ ) and streamlines at the $850 \mathrm{hPa}-\mathrm{level}(1.5 \mathrm{~km})$ calculated with the AIR model with 3-km resolution for 0200 UTC (1000 LT) on 30 December 2009. The model domain is the same as in Fig. 10
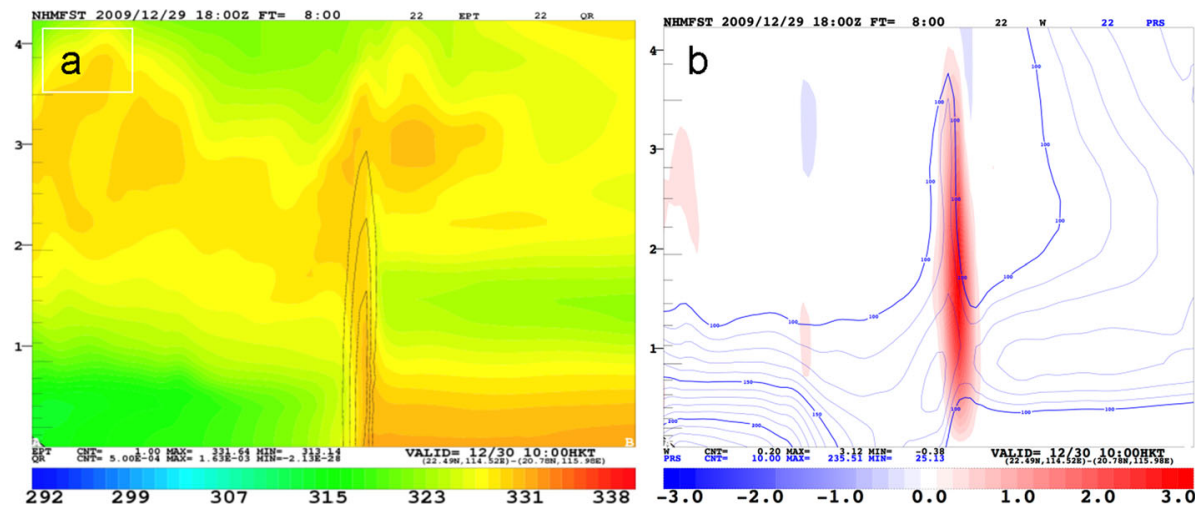

Fig. 12 Vertical cross-sections along the line inserted in Fig. 11 calculated with the AIR model with 3-km resolution for 0200 UTC (1000 LT) on 30 December 2009. The units on the vertical axis are km. a Vertical cross-section of equivalent potential temperature in kelvin (colour coding) and of specific humidity of rain water in units of $\mathrm{kg} \mathrm{kg}^{-1}$ (black contour lines with intervals of $5 \times 10^{-4} \mathrm{~kg} \mathrm{~kg}^{-1}$ ). b Vertical cross-sections of the vertical velocity $(w)$ in $\mathrm{m} \mathrm{s}^{-1}$ (colour coding) and of pressure perturbation exceeding $100 \mathrm{~Pa}$ (blue contour lines with intervals of $10 \mathrm{~Pa})$

this position, strong uplift of air with a speed of $2-3 \mathrm{~m} \mathrm{~s}^{-1}$ is found that is associated with a vertical pressure perturbation (Fig. 12b) due to vertical wind shear between the near-surface layer (below $1 \mathrm{~km}$ in altitude) and air masses aloft that favours the dynamical process in 
forming the notches in the wind front. Thus these last two figures give a good insight into the mechanism that leads to the generation of the rain cells at the frontal boundary. The vertical extent of the rain cells as forecast by the numerical model is quite consistent with vertical scans of the radar reflectivity obtained by the Hong Kong weather radar (not shown here), which shows that the rain cell reaches up to $4-6 \mathrm{~km}$.

\section{Summary}

For the first time, a coastal wind front over the South China Sea associated with the freshening of the north-east monsoon caused by the merging of two anticyclonic regions over the Chinese continent has been investigated using multi-sensor satellite data, weather radar data, and a high-resolution atmospheric numerical model. The observational data have been compared with numerical model data obtained by the pre-operational version of the Atmospheric Integrated Rapid-cycle (AIR) forecast model system of the Hong Kong Observatory. While winter monsoon surges associated with cold-air outbreaks, also called northerly surges, have been studied quite extensively, this does not apply to other high wind speed events associated with the north-east monsoon that also give rise to wind fronts over the South China Sea. While northerly surges (cold-air outbreaks) are associated with continental cold air flowing from the north onto the South China Sea, the high-wind-speed event described herein is associated with cold air flowing from the north-east along the Chinese coast through the Strait of Taiwan into the South China Sea. Since the air has travelled a long distance over warm waters, this event is associated only with a small change in air temperature during passage at Hong Kong. Furthermore, in Hong Kong, it is associated only with a small change in wind speed and direction, but offshore, between 30 and $130 \mathrm{~km}$ south of the coastline, the wind speed and direction change significantly. The wind front generated by the freshening of the north-east monsoon is quite similar to wind fronts generated by cold-air outbreaks (Alpers et al. 2012). As in cold-air outbreaks, also during this event the front is generated by the collision of two air masses having different temperatures, flow directions, and speeds. This generates a line of convergence near the sea-surface with the potential to develop rain cells. Previous investigations using SAR images have shown that such convergent airflows associated with synoptic-scale flow can generate quite sharp wind fronts having widths of 2 km (Young et al. 2005; Brümmer et al. 2010; Alpers et al. 2012).

It is well known that in cold surges the strongest precipitation is coincident with the leading edge of the surface front (Locatell et al. 1995). Generally, precipitation is not uniform along frontal rainbands. Instead, the rainbands are broken up into rain cells with heavy precipitation and areas with light precipitation (Hobbs 1978). Although the rain cells are roughly oriented in a line, they are generally offset from each other causing the rainband to have a zig-zag shape on a small scale. These features of rain bands previously observed at cold fronts, are also observed at the front investigated herein.

When comparing the measurements with simulations from the pre-operational version of the AIR forecast model of the Hong Kong Observatory with 10-km resolution, we find that this model is capable of reproducing quite well the features visible on the satellite and weather radar images, although with some deficiencies, e.g., overestimating the wind speed in the lee of coastal mountains east of Hong Kong, which is very likely due to the fact that the model does not account properly for the shadowing of the flow by the coastal mountains.

Another objective of this paper was to test the performance of the AIR model with respect to the generation of rain cells at frontal boundaries. This has been possible by using the AIR model with 3-km resolution and comparing model results with features visible on a high- 
resolution SAR image and on a quasi-simultaneously acquired weather radar image (time difference only $1 \mathrm{~min}$ ). The SAR image, having a resolution of $150 \mathrm{~m}$, reveals fine-scale features of the wind front by means of variation of the sea-surface roughness, in particular it shows notches (dents) in the frontal line and embedded rain cells. The model reproduces quite well the position of the notches, where rain cells are generated, and it shows that the vorticity of the airflow is increased at the position of the notches leading to uplift of warmer, moister air from the sea-surface to higher levels.

Since the event described is associated with strong vertical wind shear, it leads to an intensification of updrafts in areas where strong rain cells are generated. It is well known that vertical wind shear significantly enhances uplift during the formation of supercells in severe storms. By analogue reasoning, the same mechanism should also apply in our case.

In summary, we conclude that the AIR model is well suited to simulating the main features of the atmospheric front observed on satellite and weather radar images on 30 December 2009 over the South China Sea. Furthermore, it provides insight into the physical mechanism leading to the generation of rain cells embedded in a wind front.

Acknowledgments We thank ESA for providing the ASAR images free of charge within the ESA-MOST Dragon project, and Gerd Müller of the Meteorological Institute of the University of Hamburg for very fruitful discussions on the interpretation of the observed atmospheric phenomena.

Open Access This article is distributed under the terms of the Creative Commons Attribution 4.0 International License (http://creativecommons.org/licenses/by/4.0/), which permits unrestricted use, distribution, and reproduction in any medium, provided you give appropriate credit to the original author(s) and the source, provide a link to the Creative Commons license, and indicate if changes were made.

\section{References}

Alpers W, Ivanov AY, Horstmann J (2009) Observations of bora events over the Adriatic Sea and Black Sea by spaceborne synthetic aperture radar. Mon Weather Rev 137:1150-1161. doi:10.1175/2008MWR2563.1

Alpers W, Huang W, Chan PW, Wong WK, Chen CM, Mouche A (2010) Atmospheric phenomena observed over the South China Sea by the Advanced Synthetic Aperture Radar onboard the Envisat satellite. In: Proceedings of the Dragon 2 Programme mid term results symposium held in Guilin, P. R. China, 17-21 May 2010. ESA Publication SP-684

Alpers W, Wong WK, Dagestad K-F, Chan PW (2012) A northerly winter monsoon surge over the South China Sea studied by remote sensing and a numerical model. Int J Remote Sens 33(23):7361-7381

Alpers W, Mouche A, Horstmann J, Ivanov AY, Barbanov V (2015) Application of a new algorithm using Doppler information to retrieve complex wind fields over the Black Sea from Envisat SAR images. Int J Remote Sens 36(3):863-881. doi:10.1080/01431161.2014.999169

Beljaars ACM, Holtslag AAM (1991) Flux parameterization over land surfaces for atmospheric models. J Appl Meteorol 30:327-341

Boyle JS, Chen T-J (1978) Synoptic aspects of the wintertime East Asian monsoon. In: Chang CP, Krishnamurti TN (eds) Monsoon meteorology. Oxford University Press, Oxford, pp 125-160

Brümmer B, Müller G, Klepp C, Spreen G, Romeiser R, Horstmann J (2010) Characteristics and impact of a gale-force storm field over the Norwegian Sea. Tellus 62:481-496. doi:10.1111/j.1600-0870.2010.00448

Chang C-P, Millard JE, Chen GTJ (1983) Gravitational character of cold surges during winter MONEX. Mon Weather Rev 111:293-307

Chang C-P, Harr PA, Chen HJ (2005) Synoptic disturbances over the equatorial South China Sea and western maritime continent during boreal winter. Mon Weather Rev 133:489-503

Chen TC, Huang WR, Yoom J (2004) Interannual variation of the East Asian cold surge activity. J Clim 17(2):401-413

Chu P-S, Park SU (1984) Regional circulation characteristics associated with a cold surge event over East Asia during Winter MONEX. Mon Weather Rev 112:955-965

Doswell CA III (2001) Severe convective storms-an overview. In: Doswell CA III (ed) Severe convective storms. Meteorological Monographs, vol 28. American Meteorological Society, Boston, pp 1-26 
Doswell CA III (2014) Severe storms. In: Njoku EN (ed) Encyclopedia of remote sensing (Encyclopedia of Earth Sciences Series). Springer, Berlin

Fairall CW, Bradley EF, Rogers DP, Edson JB, Young GS (1996) Bulk parameterization of air-sea fluxes for Tropical Ocean Global Atmosphere Coupled Ocean-Atmosphere Response Experiment. J Geophys Res 101:3747-3764

Hobbs PV (1978) Organization and structure of clouds and precipitation on the mesoscale and microscale in cyclonic storms. Rev Geophys Space Phys 16:741-755

Holton JR (1992) An introduction to dynamic meteorology, 3rd edn. Academic Press, New York, 511 pp

Horstmann J, Koch W (2005) Comparison of SAR wind field retrieval algorithms to a numerical model utilizing ENVISAT ASAR data. IEEE J Ocean Eng 30:508-515. doi:10.1109/JOE.2005.857514

Johnson RH, Zimmermann JR (1986) Modification of the boundary layer over the South China Sea during a Winter MONEX cold surge even. Mon Weather Rev 114:2004-2015

Lim H, Chang C-P (1981) A theory for midlatitude forcing of tropical motions during winter monsoon. J Atmos Sci 38:2377-2392

Locatell JD, Martin JE, Hobbs PV (1995) Development and propagation of precipitation cores on cold fronts. J Atmos Res 38:177-206

Melsheimer C, Alpers W, Gade M (1998) Investigation of multifrequency/multipolarization radar signatures of rain cells derived from SIR-C/X-SAR data. J Geophys Res 103:18867-18884

Monaldo FM, Thompson DR, Beal RC, Pichel WG, Clemente-Colon P (2001) Comparison of SAR-derived wind speed with model predictions and ocean buoy measurements. IEEE Trans Geosci Remote Sens 39:2587-2600

Monaldo FM, Kerboal V, SAR Wind Team (2003) The SAR measurement of ocean surface winds: an overview. In: Proceedings of the 2nd workshop on coastal and marine applications of SAR, 8-12 Sept 2003, Svalbard, Norway

Mouche A, Collard F, Chapron B, Dagestad K-F, Guitton G, Johannessen JA, Kerbaol V, Hansen MW (2012) On the use of Doppler shift for sea surface wind retrieval from SAR. IEEE Trans Geosci Remote Sens 50:2901-2909. doi:10.1109/TGRS.2011.2174998

Ramage CS (1971) Monsoon meteorology. Academic Press, New York, 296 pp

Rotunno R, Klemp JB (1982) The influence of the shear-induced pressure gradient on thunderstorm motion. Mon Weather Rev 110:136-151

Saito K, Fujita T, Yamada Y, Ishida J, Kumagai Y, Aranami K, Ohmori S, Nagasawa R, Kumagai S, Muroi C, Kato T, Eito H, Yamazaki Y (2006) The operational JMA non-hydrostatic model. Mon Weather Rev 134:1266-1298

Sikora TD, Young GS, Winstead TS (2006) A novel approach to marine wind speed assessment using synthetic aperture radar. Weather Forecast 21:109-115

Stoffelen A, Anderson D (1997) Scatterometer data interpretation: estimation and validation of the transfer function CMOD4. J Geophys Res 102:5767-5780

Valenzuela GR (1978) Theories for the interaction of electromagnetic and oceanic waves: a review. BoundaryLayer Meteorol 13:61-85

Wong WK (2010) Development of operational rapid update non-hydrostatic NWP and data assimilation systems in the Hong Kong Observatory. Paper presented at the third international workshop on prevention and mitigation of meteorological disasters in Southeast Asia, 1-4 March, 2010, Beppu, Japan. Available on-line: http://www.weather.gov.hk/publica/reprint/r882.pdf

Wu MC, Chan JCL (1995) Upper-level features associated with winter monsoon surges over South China. Mon Weather Rev 123:662-680

Wu MC, Chan JCL (1997) Surface features of winter monsoon surges over South China. Mon Weather Rev 125:317-340

Yang X, Li X, Pichel W, Li Z (2011) Comparison of ocean surface winds from ENVISAT ASAR, Metop ASCAT scatterometer, buoy measurements, and NOGAPS model. IEEE Trans Geosci Remote Sens. doi:10.1109/TGRS.2011.2159802

Young GSA, Sikora TD, Winstead NS (2005) Use of synthetic aperture radar in finescale surface analysis of synoptic-scale fronts at sea. Weather Forecast 20:311-327

Zhang Y, Sperber KR, Boyle JS (1997) Climatology and inter-annual variation of the East Asian winter monsoon: results from the 1979-95 NCEP-NCAR reanalysis. Mon Weather Rev 125:2605-2619 